\title{
Hubungan Pengetahuan Dan Sikap Lansia Dengan Pencegahan Hipertensi Di Desa Gotting Sidodadi Kabupaten Asahan
}

\author{
Nixson Manurung \\ Email : nixsonmanurung@gmail.com
}

\begin{abstract}
Hipertensi adalah tekanan sistolik $>140 \mathrm{mmHg}$ dan tekanan darah diastolik $\geq$ $90 \mathrm{mmHg}$ atau bila pasien memakai obat anti hipertensi. Tekanan darah tinggi atau hipertensi berarti tekanan (tegangan) yang tinggi dalam arteri (Mansjoer, 2000). Lanjut usia (lansia) merupakan figur tersendiri dalam kaitannya dengan sosial budaya bangsa. Mereka termasuk golongan yang patut dihargai dan dihormati sesuai dengan eksistensinya dalam strata kemasyarakatan, dalam kehidupan sosial nasional, lanjut usia merupakan sumber daya yang dinilai sesuai dengan pengetahuan dan pengalaman kehidupan yang dimilikinya yang patut dimanfaatkan bagi masyarakat keseluruhan sebagai salah satu hasil pembangunan adalah meningkatkan umur harapan hidup waktu lahir sejalan dengan hal tersebut maka jumlah lanjut usia pun meningkat (Nugroho, 2005). Pengembangan suatu program pembinaan kesehatan lanjut usia dengan strategi pendekatan edukatif melalui institusi pelayanan kesehatan terutama puskesmas dan posyandu lansia (lanjut usia) dan institusi lainnya, dengan adanya program diharapkan terbentuk suatu masyarakat lansia yang berdayaguna, mandiri dan aktif dalam menjalankan fungsi kehidupannya secara optimal (Depkes RI, 2002). Tujuan penelitian ini adalah mengetahui hubungan pengetahuan dan sikap lansia terhadap pencegahan hipertensi di Desa Gotting Sidodadi Kabupaten Asahan Tahun 2018Berdasarkan uraian diatas peneliti tertarik untuk melakukan penelitian tentang "Hubungan Pengetahuan Dan Sikap Lansia Dengan Pencegahan Hipertensi Di Desa Gotting Sidodadi Kabupaten Asahan Tahun 2018
\end{abstract}

Kata Kunci : Pengetahuan dan Sikap, Hipertensi, Lansia 


\section{Pendahuluan}

Hipertensi adalah tekanan sistolik $>140 \mathrm{mmHg}$ dan tekanan darah diastolik $\geq 90 \mathrm{mmHg}$ atau bila pasien memakai obat anti hipertensi. Tekanan darah tinggi atau hipertensi berarti tekanan (tegangan) yang tinggi dalam arteri (Mansjoer, 2000)

WHO menyatakan hipertensi merupakan silent killer karena banyak masyarakat tidak menaruh perhatian terhadap penyakit yang kadang dianggap sepele tanpa menyadari bahwa penyakit ini sangat berbahaya dari berbagai kelainan yang telah fatal, seperti kelainan pembuluh darah, jantung dan gagal ginjal, bahkan pecahnya pembuluh darah kapiler otak atau sering disebut stroke (Mansjoer, 2008).

Hipertensi didunia dengan insiden yang bervariasi akhir-akhir ini insiden dan prevalensi meningkat dengan bertambahnya usia harapan hidup. Di Amerika Serikat dikatakan bahwa populasi kulit putih usia 60-69 tahun prevalensinya sekitar 35\% yang meningkat menjadi $50 \%$ pada usia diatas 69 tahun.Penelitian pada 300.000 populasi berusia $65-115$ tahun (rata-rata $82,7 \% /$ tahun) yang dirawat diinstitusi lanjut usia didapatkan prevalensi pada saat mulai dirawat sebesar $32 \%$ dari penderita ini $70 \%$ diberikan obat anti hipertensi dan sudah mengalami komplikasi akibat penyakitnya diantaranya penyakit jantung koroner $100 \%$, penyakit jantung kongesty (22 \%). (Hadi, 2009).

Dengan meningkatnya harapan hidup penduduk Indonesia, maka dapat diperkirakan bahwa insiden penyakit degenaratif akan meningkat pula, penyakit yang mempunyai tingkat morbilitas dan mortalitas tinggi adalah hipertensi. Hipertensi pada usia lanjut menjadi lebih tinggi, lebih penting lagi mengingat bahwa patogenesis perjalanan penyakit dan pelaksanaannya tidak seluruhnya sama dengan hipertensi pada usia muda.

Berdasarkan uraian diatas peneliti tertarik untuk melakukan penelitian tentang "Hubungan Pengetahuan Dan Sikap Lansia Dengan Pencegahan Hipertensi Di Desa Gotting Sidodadi Kabupaten Asahan Tahun 2018".

\section{Metode}

Penelitian ini menggunakan metode penelitian survei yang bersifat deskriptif analitik, untuk mengetahui hubungan pengetahuan dan sikap lansia terhadap pencegahan hipertensi di Desa Gotting Sidodadi Kecamatan B.P Mandoge Kabupaten Asahan Tahun 2018. Penelitian dilakukan di Desa Gotting Sidodadi Kecamatan B.P Mandoge Kabupaten Asahan yang di mulai pada bulan Agustus - September 2018.

Populasi dalam penelitian ini ialah seluruh usia lanjut antara 60 sampai 74 tahun (elderly) yang ada di Desa Gotting Sidodadi Kecamatan B.P Mandoge Kabupaten Asahan sebanyak 31 orang.

Data yang telah dikumpulkan selanjutnya diolah dengan ara editing, coding, dan tabulating. Data dianalisa dengan menggunakan program komputerisasi atau SPSS versi 15.0. Sedangkan uji yang digunakan adalah Uji Statistik Chi Square

\section{Hasil dan Pembahasan Univariat}

Tabel 1: Distribusi Pengetahuan Responden Di Desa Gotting Sidodadi Kabupaten Asahan Tahun 2018

\begin{tabular}{|c|c|c|c|}
\hline No & Pengetahuan & Jumlah & Presentase ( $\%$ \%) \\
\hline 1. & Kurang Baik & 8 & 25,8 \\
\hline 2. & Cukup & 12 & 38,7 \\
\hline 3 & Baik & 11 & 35,5 \\
\hline \multicolumn{2}{|c|}{ Jumlah } & $\mathbf{3 1}$ & $\mathbf{1 0 0}$ \\
\hline
\end{tabular}

Berdasarkan Tabel di atas dapat di lihat bahwa dari 31 responden yang memiliki pengetahuan kurang sebanyak 8 orang $(25,8 \%$ ) $\quad$ Pengetahuan cukup sebanyak 12 orang $\left(38,7^{\circ} / 0\right)$ serta 
pengetahuan baik sebayak 11 orang $\left(35^{\circ} / 0\right)$.

Tabel 2. Distribusi sikap responden di Desa Gotting Sidodadi Tahun 2018

\begin{tabular}{|l|c|c|c|}
\hline No. & Sikap & Jumlah & Persentase \\
\hline 1. & Kurang Baik & 7 & 22,6 \\
\hline 2. & Cukup & 18 & 58,1 \\
\hline 3. & Baik & 6 & 19,4 \\
\hline \multicolumn{2}{|c|}{ Jumlah } & $\mathbf{3 1}$ & $\mathbf{1 0 0}$ \\
\hline
\end{tabular}

Berdasarkan tabel di atas dapat di lihat bahwa dari 31 responden yang memiliki sikap kurang sebanyak 7 orang $(22,6$ $\%$ ) sikap cukup sebanyak 18 orang $(58,1 \%)$, serta sikap baik sebanyak 6 orang $\left(19,4^{\circ} /\right)$.

Tabel 3. Distribusi pencegahan hipertensi lansia di desa Gotting Sidodadi tahun 2018

\begin{tabular}{|c|c|c|c|}
\hline No. & $\begin{array}{c}\text { Pencegahan } \\
\text { Hipertensi }\end{array}$ & Jumlah & Persentase \\
\hline 1 & Kurang Baik & 14 & 45,1 \\
\hline 2 & Cukup & 11 & 35,5 \\
\hline 3 & Baik & 6 & 19,4 \\
\hline \multicolumn{2}{|c|}{ Jumlah } & $\mathbf{3 1}$ & $\mathbf{1 0 0}$ \\
\hline
\end{tabular}

Berdasarkan tabel di atas dapat di lihat bahwa dari 31 responden yang melakukan pencegahan hipertensi dengan kategori kurang sebanyak 14 orang $\left(45,2^{\circ} / 0\right)$, Kategori cukup sebanyak 11 orang $(35,5 \%)$, serta kategori Baik sebanyak 6 orang $\left(19,4^{\circ} \%\right)$.

Tabel 4. Tabulasi Silang Antara Pengetahuan Lansia Dengan Pencegahan Hipertensi di Desa Gotting Sidodadi Kabupaten Asahan Tahun 2018

\begin{tabular}{|c|c|c|c|c|c|c|c|c|c|}
\hline \multirow{3}{*}{$\begin{array}{l}\text { Pengeta } \\
\text { huan }\end{array}$} & \multicolumn{6}{|c|}{ Pencegahan Hipertensi } & \multirow{2}{*}{\multicolumn{2}{|c|}{ Jumlah }} & \multirow{2}{*}{ Asymp.sigbalik dengan pencegahan hipertens } \\
\hline & \multicolumn{2}{|c|}{ Kurang } & \multicolumn{2}{|c|}{ Cukup } & \multicolumn{2}{|r|}{ Baik } & & & \\
\hline & $f$ & $\%$ & f & $\%$ & $f$ & $\%$ & $f$ & $\%$ & (2sided) palda lansia \\
\hline Kurang Baik & 2 & 6,5 & 4 & 12,9 & 2 & 6,5 & 8 & 25,8 & \multirow{4}{*}{$\begin{array}{l}\text { sepanyak } 1 \text { orang }(3,2 \%) \text {. Hasil Uji chi- } \\
\text { square dengan tingkat kepercayaan } 95 \\
\%(\alpha=0,05) \text { diperoleh } P<0,05 \text { jadi } \\
(026<05 \text { artinva ada hubungan }\end{array}$} \\
\hline \multirow[b]{2}{*}{ Baik } & 4 & 12,9 & 7 & 22,6 & 1 & 3,2 & 12 & 38,7 & \\
\hline & 8 & 25,8 & 0 & 0 & 3 & 9,7 & 11 & 35,5 & \\
\hline Total & 14 & 45,2 & 11 & 35,5 & 6 & 19,4 & 31 & 100 & \\
\hline
\end{tabular}

Berdasarkan Tabel diatas, menunjukan bahwa dari 8 responden yang berpengetahuan kurang dengan pencegahan hipertensi lansia juga kurang sebanyak 2 orang (6,5\%). Dari 12 Responden yang berpengetahuan cukup dengan pencegahaan hipertensi Lansia Kategori cukup sebanyak 7 orang ( 22,6 \%). Dari 11 Responden yang berpengetahuan baik dengan pencegahaan hipertensi Lansia dengan Kategori baik sebanyak 3 orang $(9,7 \%)$. Hasil Uji chi-square dengan tingkat kepercayaan $95 \%(\alpha=0,05)$ diperoleh $P$ $<0,05$ jadi 0,035 $<0,05$, artinya ada hubungan pegetahuan Lansia dengan Pencegahaan Hipertensi di Desa Gotting Sidodadi.

Tabel 5 Hubungan Sikap Lansia dengan pencegahaan hipertensi di Desa Gotting Sidodadi Kabupaten AsahanTahun 2018.

\begin{tabular}{|c|c|c|c|c|c|c|c|c|c|}
\hline \multirow{3}{*}{ Sikap } & \multicolumn{6}{|c|}{ Pencegahan Hipertensi Lansia } & & & \multirow{3}{*}{$\begin{array}{c}\text { Asym } \\
\text { p.Sig } \\
\text { ( } \\
\text { 2sided } \\
\text { ) } \\
0,026\end{array}$} \\
\hline & \multicolumn{2}{|c|}{ Kurang } & \multicolumn{2}{|c|}{ Cukup } & \multicolumn{2}{|c|}{ Baik } & \multicolumn{2}{|c|}{ Jumlah } & \\
\hline & $f$ & $\%$ & $f$ & $\%$ & $f$ & $\%$ & $\mathrm{~F}$ & $\%$ & \\
\hline Kurang Baik & 4 & 12,9 & 3 & 9,7 & 0 & 0 & 7 & 22,6 & \\
\hline Cukup & 9 & 29,0 & 7 & 22,6 & 1 & 6,5 & 18 & 58,1 & \\
\hline Baik & 1 & 3,2 & 1 & 3,2 & 4 & 12,9 & 6 & 19,3 & \\
\hline Total & 14 & 45,1 & 11 & 35,5 & 6 & 19,4 & 31 & 100 & \\
\hline
\end{tabular}

Berdasarkan Tabel diatas,menunjukan bahwa dari 7 Responden ( 22,6\%) yang bersikap kurang dengan pencengahan hipertensi pada Lansia dengan kategori kurang sebanyak 4 orang ( $12,9 \%)$. Dari 18 Responden ( 58,1 \% ) yang bersikap cukup dengan pencegahan hipertensi pada lansia dengan kategori cukup sebanyak 9 orang ( 29,0 \% ). Dari 6 responden ( $19,3 \%$ ) yang bersikap pada lansia dengan kategori baik sebanyak 1 orang (3,2\%). Hasil Uji chisquare dengan tingkat kepercayaan 95 $0,026<0,05$, artinya ada hubungan 
Sikap Lansia dengan Pencegahaan Hipertensi di Desa Gotting Sidodadi.

\section{Pembahasan}

Berdasarkan hasil penelitian menunjukkan bahwa pengetahuan yang baik akan memiliki pencegahan yang baik terhadap penyakit hipertensi yaitu 11 Orang (35,5\%), sedangkan responden yang berpengetahuan kurang baik memiliki pencegahan hipertensi kurang baik berjumlah 8 orang $(25,8 \%)$. Dari hasil Uji Chi-Square dengan taraf kepercayaan $95 \%(\alpha=$ $0,05)$ diperoleh hasil $P<0.05$. jadi $0,035<0,05$, artinya Ada hubungan antara pengetahuan lansia dengan pencegahan hipertensi di Desa Gotting Sidodadi.

Hal ini sesuai dengan teori Sarwono (2006) bahwa memberikan pengetahuan tentang kebiasaan hidup yang baik akan terjadi peningkatan mutu pengetahuan dan perilaku kesehatan dalam diri individu yang berdasarkan kesadaran dan kemauan individu yang bersangkutan. pengetahuan seseorang akan bertambah dengan diperolehnya informasi-informasi tertentu sehingga akan terjadi peningkatan pengetahuan. Dengan peningkatan pengetahuan tersebut maka akan terjadi peningkatan terhadap derajat kesehatan dalam diri individu yang berdasarkan kesadaran dan kemauan individu untuk mencegah suatu penyakit.

Hal ini tidak sejalan dengan pendapat Notoadmodjo (2006), hambatan yang paling besar dirasakan dalam mewujudkan perilaku hidup sehat masyarakat yaitu faktor pendukungnya, dari penelitian penelitian yang ada terungkap meskipun kesadaran dan pengetahuan masyarakat sudah tinggi tentang kesehatan, namun praktek tentang kesehatan atau perilaku hidup sehat masih rendah. Setelah dilakukan penelitian oleh WHO pada tahun 2006 di negara - negara berkembang, ternyata faktor pendukung atau sarana dan prasarana tidak mendukung masyarakt untuk berperilaku hidup sehat. Misalnya, meskipun kesadaran dan pengetahuan orang atau masyarakat tentang kesehatan sudah tinggi, tetapi apabila didukung oleh fasilitas, yaitu tersedianya sarana dan prasarana air bersih, jamban sehat, makanan yang bergizi, fasilitas imunisasi, pelayanan kesehatan, posyandu lansia, maka mereka sulit untuk mewujudkan perilaku sehat tersebut, sehingga meningkatkan derajat angka kesakitan.

Menurut asumsi penulis, penyebab kurangnya pengetahuan lansia tentang pencegahan Hipertensi di Desa Gotting Sidodadi Lansia tidak berusaha untuk memperoleh informasi - informasi tentang cara pencegahan diare dan pada umumnya Lansia tidak begitu aktif dalam kegiatan posyandu Lansia untuk mengikuti penyuluhan yang berguna untuk menambah pengetahuan Lansia, serta kurangnya peran serta keluarga dalam pemberian dukungan terhadap kesehatan pada lansia terutama terhadap pencegahan hipertensi.

\section{Kesimpulan}

Dari hasil penelitian mengenai hubungan dan sikap lansia dengan pencegahan hipertensi di Desa Gotting Sidodadi Kabupaten Asahan Tahun 2018, dapat disimpulkan sebagai berikut :

1. Dari 31 Lansia di Desa Gotting Sidodadi yang memiliki pengetahuan kurang sebanyak 8 Orang $(25,8 \%)$ dengan pencegahan hipertensi juga 
kurang sebanyak 2 orang $(6,5 \%)$. Dari 12 Responden yang berpengetahuan cukup dengan pencegahan hipertensi juga cukup sebanyak 7 Orang (22,7\%). Dari 11 Responden yang berpengetahuan baik dengan pencegahan hipertensi yang baik sebanyak 3 orang (9,7\%). Dari hasil Uji Chi-Square dengan taraf kepercayaan $95 \%$ $(\alpha=0,05)$ diperoleh hasil $P<$ 0.05 . jadi $0,035<0,05$, artinya Ada hubungan yang signifikan antara pengetahuan lansia dengan pencegahan hipertensi di Desa Gotting Sidodadi.

2. Dari 31 lansia di Desa Gotting Sidodadi Kabupaten Asahan yang bersikap kurang sebanyak 7 orang dengan pencegahan hipertensi yang kurang sebanyak 4 orang (12, $9 \%$ ). Dari 18 Responden yang bersikap cukup dengan pencegahan hipertensi juga cukup sebanyak 9 orang $(29,0 \%)$ dari 6 responden yang bersikap baik dengan pencegahan hipertensi dengan kategori baik sebanyak 1 orang ( $3,2 \%)$. di Desa Gotting Sidodadi Kabupaten Asahan bahwa dari hasil Uji ChiSquare dengan taraf kepercayaan $95 \%(\alpha=0,05)$ diperoleh hasil $P<0.05$. jadi $0,026<0,05$, artinya Ada hubungan yang signifikan antara sikap lansia dengan pencegahan hipertensi di Desa Gotting Sidodadi.

\section{Saran}

1. Diharapkan kepada masyarakat khususnya lansia agar mampu melakukan pencegahan hipertensi di Desa
Gotting Sidodadi dan lebih banyak lagi mencari informasi - informasi mengenai pencegahan hipertensi kepada palayanan kesehatan dan dapat juga melalui media elektronik, media cetak maupun buku - buku mengenai pencegahan hipertensi.

2. Diharapkan peningkatan pelayanan kesehatan dan penyuluhan penyuluhan pada lansia dalam pencegahan hipertensi baik disarana pelayanan kesehatan maupun diposyandu lansia.

\section{Daftar Pustaka}

Aditam TT. 2009. Hindari Hipertensi Garam 1 Sendok Teh Per Hari. http://dinkesbonebalonge.com. Diakses tanggal 29 Juni 2011. Pukul 21:21 Wib.

Arikunto. S, 2010. Prosedur Penelitian. Cetakan Ke Empat Belas. Jakarta: Rineka Cipta.

Bandiyah S. 2009. Lanjut Usia dan Keperawatan Genetik. Yogyakarta: Nuha Medika.

Brunner \& Suddarth. 2000. Keperawatan Medical Bedah. Edisi 8. Jakarta: EGC.

Darmoto Buedi \& Martono Hadi. 2009. Geriatri Ilmu Kesehatan. Jakarta: EGC.

Depkes RI. 2002. Pembinaan Kesehatan Lansia. Jakarta: Departemen Kesehatan Republik Indonesia.

http://www-news-medical.com 
http://www.hariansumutpos.com/2010 /03/peran-keluarga-pentingbagi-pasien-stroke-html diakses pada tanggal 2 Mei 2010. Pukul 22:32.21. Wib

Masjoer, A. 2000. Kapita Selekta Kedokteran. Jakarta: EGC.

Marliani L, Tantan S. 2007. Hipertensi. Cetakan Kedua. Jakarta: Gramedia.

Muhammadun AS. 2010. Hidup Bersama Hipertensi. Yogyakarta: In-Boks

Nissonline. 2009. Insiden Hipertensi. Dikutip pada tanggal $04 \mathrm{Mei}$ 2011. Pukul 11.30 Wib.

Notoatmodjo. S. 2003. Ilmu Kesehatan Masyarakat. Cetakn Kedua. Jakarta: Rineka Cipta.

. S. 2010. Promosi Kesehatan. Jakarta: Rineka Cipta.

Nugroho, Wahyudi. 2005. Perawatan Lanjut Usia. Jakarta: EGC.

i. 2009. Keperawatan Gawat Darurat. Edisi 2. Jakarta: EGC.

.Lumban Tobing SM. 2005. Stroke. Jakarta: Fakultas Kedokteran Universitas Indonesia.

Setiadi. 2007. Riset Keperawatan. Yogyakarta: Graha IImu.

Sudarmoko, A. 2010. Tetap Tersenyum Melawan Hipertensi. Yogyakarta: Atma Media Perss. 